\title{
Transition from Plasticity to Brittleness in Cu-Zr-Based Bulk Metallic Glasses
}

\author{
Qingsheng Zhang*, Wei Zhang and Akihisa Inoue \\ Institute for Materials Research, Tohoku University, Sendai 980-8577, Japan
}

The effects of addition of $\mathrm{Al}$ and $\mathrm{Ag}$ on the mechanical properties of the $\mathrm{Cu}_{50} \mathrm{Zr}_{50}$ alloy are investigated. It is found that the plasticity of the $\mathrm{Cu}-\mathrm{Zr}$-based BMGs decreases as the content of the alloying elements of $\mathrm{Al}$ and $\mathrm{Ag}$ increases. A clear transition from plasticity to brittleness occurs for the $\mathrm{Cu}-\mathrm{Zr}$-based BMGs with increasing the content of $\mathrm{Al}$ and $\mathrm{Ag}$. Combining with previous work on the plasticity or brittleness of the $\mathrm{Cu}$-Zr-based BMGs, the role of the atomic binding force between the solute and solvent atoms is suggested to understand the transition from plasticity to brittleness for the Cu-Zr-based BMGs. [doi:10.2320/matertrans.MF200620]

(Received December 22, 2006; Accepted March 5, 2007; Published May 25, 2007)

Keywords: bulk metallic glasses, copper-zirconium-based alloys, compression tests, ductile-to-brittle transition

\section{Introduction}

Bulk metallic glasses (BMGs) have been developed in a number of alloy systems in the last decade. ${ }^{1)}$ Because of their unique physical and mechanical properties, BMGs have been considered as the promising structural materials. As compared with the conventional crystalline metals, the deformation of BMGs is concentrated into the localized shear bands. As a result, BMGs typically display limited plastic flow in compression $(0 \%-2 \%)$ and none in tension at room temperature. BMGs can be divided into two types: tough BMGs and brittle BMGs. ${ }^{2,3)}$ The tough BMGs exhibit high fracture toughness $\left(\mathrm{K}_{\mathrm{c}}>20 \mathrm{MPa} \mathrm{m}^{1 / 2}\right)$ and a vein pattern of fracture surface with high local plasticity arising from instabilities in the band of lowered viscosity. ${ }^{4-7)}$ The Zr-based, Pd-based, $\mathrm{Cu}$-based and Ti-based BMGs belong to the tough BMGs. The brittle BMGs are both globally and locally brittle. Typical characteristics of the brittle BMGs are the low fracture toughness $\left(\mathrm{K}_{\mathrm{c}}<5 \mathrm{MPa} \mathrm{m}^{1 / 2}\right)$ and a flat mirror facture surface. ${ }^{8)}$ BMGs based on magnesium and iron are the brittle BMGs. In addition, the precipitation of the crystalline phase always results in low ductility of BMGs. ${ }^{9)}$ Recently, several correlations were established in order to understand the brittleness or plasticity of the BMGs. It was reported that there existed a correlation between the fracture toughness and plastic process zone size for various glasses. ${ }^{8)}$ Lewandowski et $_{\text {al. }}{ }^{2)}$ found another clear correlation between the energy of fracture $\mathrm{G}$ and elastic modulus ratio $\mu / \mathrm{B}$ for metallic glasses, which showed that a brittle-to-tough transition occurs at a critical value of $\mu / \mathrm{B}>0.41-0.43$ (or, equivalently, with Poisson's ratio $v>0.31-0.32$ ). Gu et al. ${ }^{10)}$ reported that the elastic moduli of Fe-Mo-C-B bulk amorphous steel changed with adding different content of lanthanides, and an onset of plasticity was observed as $v$ approached 0.32 from below. They also suggested that the brittleness of metallic glasses could be alleviated by alloying elements with high $v$ as constituents, or introducing the elements with strong interatomic interaction. ${ }^{2,10)}$

It is well known that $\mathrm{Cu}-\mathrm{Zr}$-based BMGs exhibit high strength and high ductility under compression tests, which is a kind of typical tough BMGs. Recently, we found that

*Correspondence author, E-mail: qszhang@imr.tohoku.ac.jp addition of $\mathrm{Al}$ and $\mathrm{Ag}$ significantly improved the glassforming ability of $\mathrm{Cu}_{50} \mathrm{Zr}_{50}$ binary alloys. ${ }^{11)}$ Interestingly, the $\mathrm{Cu}-\mathrm{Zr}$-based BMGs were found to make a transition from plasticity to brittleness with increasing the content of $\mathrm{Al}$ and Ag. It is a useful work to investigate the effects of the alloying elements on the plasticity or brittleness of the BMGs, which will help us to understand the nature of the plasticity or brittleness of the BMGs and develop the ductile BMGs. In this work, the compressive properties of the $\mathrm{Cu}-\mathrm{Zr}$ based BMGs with different contents of $\mathrm{Al}$ and $\mathrm{Ag}$ were examined, and the effect of the content of alloying elements on the plasticity or brittleness of the $\mathrm{Cu}-\mathrm{Zr}$-based BMGs was also discussed.

\section{Experimental Methods}

Multicomponent alloy ingots with nominal composition $\left(\mathrm{Cu}_{0.5} \mathrm{Zr}_{0.5}\right)_{100-x}\left(\mathrm{Al}_{0.5} \mathrm{Ag}_{0.5}\right)_{x}(x=4,8,12,16,20)$ were prepared by arc melting mixtures of $\mathrm{Cu}, \mathrm{Zr}, \mathrm{Al}$ and $\mathrm{Ag}$ with a purity of $99.99 \%, 99.5 \%, 99.99 \%$ and $99.99 \%$, respectively, in a high purity argon atmosphere. Bulk cylindrical rods were prepared by copper mold casting in an argon atmosphere. The structure of the as-cast samples was examined by X-ray diffraction (XRD). Room temperature compression tests were carried out using an Instron testing machine and the strain rate was $5 \times 10^{-4} \mathrm{~s}^{-1}$. The strain gages were used to measure the elastic modulus. The test specimen had a cylindrical form of $2 \mathrm{~mm}$ in diameter and $4 \mathrm{~mm}$ in height. Fracture surface was examined by scanning electron microscopy (SEM).

\section{Results}

Before compression tests, all the samples were examined for amorphicity by XRD. Figure 1 shows the nominal compressive stress-strain curves of the $\left(\mathrm{Cu}_{0.5} \mathrm{Zr}_{0.5}\right)_{100-x^{-}}$ $\left(\mathrm{Al}_{0.5} \mathrm{Ag}_{0.5}\right)_{x}$ as-cast rods with a diameter of $2 \mathrm{~mm}$. The elastic moduli had been calibrated using the strain gages glued on the samples. For the $\mathrm{Cu}_{48} \mathrm{Zr}_{48} \mathrm{Al}_{2} \mathrm{Ag}_{2} \mathrm{BMG}$, the compressive fracture strength $\left(\sigma_{\mathrm{f}}\right)$, yield strength $\left(\sigma_{\mathrm{y}}\right)$ and plastic strain $\left(\varepsilon_{\mathrm{f}}\right)$ are $1834 \mathrm{MPa}, 1790 \mathrm{MPa}$ and $2.37 \%$, respectively. As the contents of $\mathrm{Al}$ and $\mathrm{Ag}$ increase, the strength increases, but the plastic strain decreases. The $\sigma_{\mathrm{f}}, \sigma_{\mathrm{y}}$ 


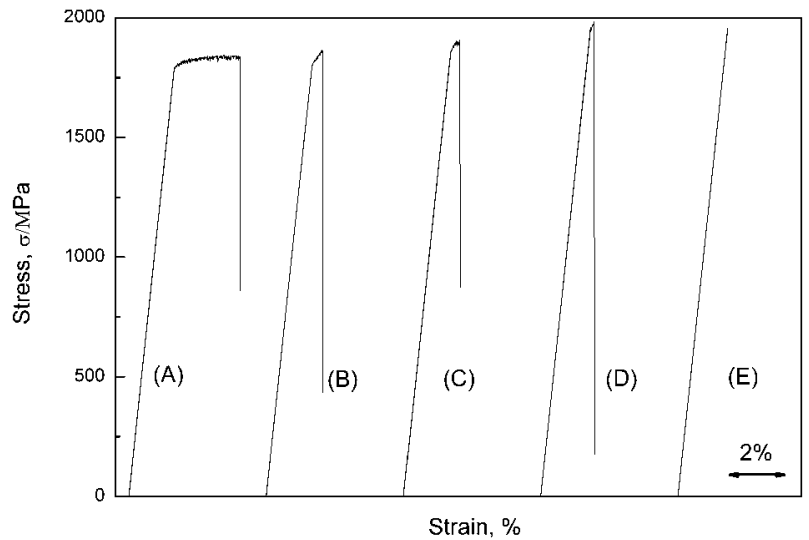

Fig. 1 Compressive stress-strain curves of the $\left(\mathrm{Cu}_{0.5} \mathrm{Zr}_{0.5}\right)_{100-x^{-}}$ $\left(\mathrm{Al}_{0.5} \mathrm{Ag}_{0.5}\right)_{x}(\mathrm{~A}: x=4 ; \mathrm{B}: x=8 ; \mathrm{C}: x=12 ; \mathrm{D}: x=16 ; \mathrm{E}: x=20)$ glassy rods with a diameter of $2 \mathrm{~mm}$.

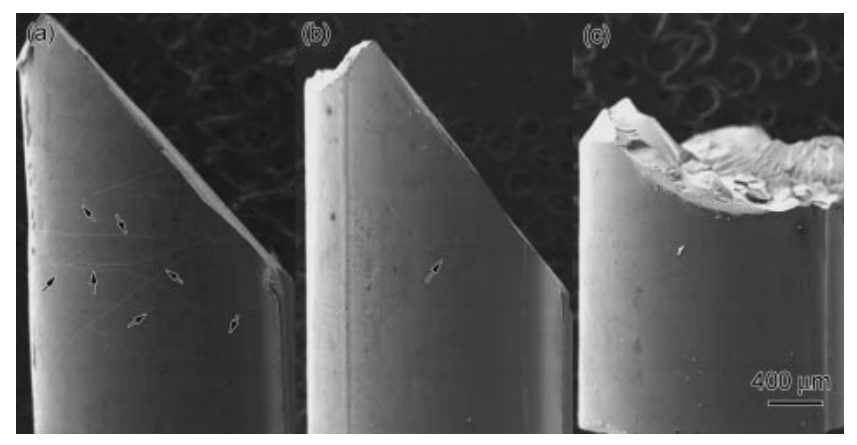

Fig. 2 SEM micrographs of the out surface of the as-cast rods with a diameter of $2 \mathrm{~mm}$ after compressive test for the $\mathrm{Cu}-\mathrm{Zr}$-based BMGs (a) $\mathrm{Cu}_{48} \mathrm{Zr}_{48} \mathrm{Al}_{2} \mathrm{Ag}_{2}$; (b) $\mathrm{Cu}_{44} \mathrm{Zr}_{44} \mathrm{Al}_{6} \mathrm{Ag}_{6}$; (c) $\mathrm{Cu}_{40} \mathrm{Zr}_{40} \mathrm{Al}_{10} \mathrm{Ag}_{10}$.

and $\varepsilon_{\mathrm{f}}$ are $1864 \mathrm{MPa}, 1810 \mathrm{MPa}$ and $0.33 \%$, respectively, for the $\mathrm{Cu}_{46} \mathrm{Zr}_{46} \mathrm{Al}_{4} \mathrm{Ag}_{4} \mathrm{BMG}$, and $1906 \mathrm{MPa}, 1868 \mathrm{MPa}$ and $0.29 \%$, respectively, for $\mathrm{Cu}_{44} \mathrm{Zr}_{44} \mathrm{Al}_{6} \mathrm{Ag}_{6}$ BMG. The $\mathrm{Cu}_{42}-$ $\mathrm{Zr}_{42} \mathrm{Al}_{8} \mathrm{Ag}_{8}$ BMG exhibits high yield strength of $1953 \mathrm{MPa}$ and low plastic strain of $0.14 \%$. For the $\mathrm{Cu}_{40} \mathrm{Zr}_{40} \mathrm{Al}_{10} \mathrm{Ag}_{10}$ $\mathrm{BMG}$, neither any yielding nor plastic strain was observed on the stress-strain curves. It is obvious that the $\left(\mathrm{Cu}_{0.5}\right.$ $\left.\mathrm{Zr}_{0.5}\right)_{100-x}\left(\mathrm{Al}_{0.5} \mathrm{Ag}_{0.5}\right)_{x}$ BMGs become brittle with increasing the content of $\mathrm{Al}$ and $\mathrm{Ag}$.

In order to simplify the analysis, we selected the $\mathrm{Cu}_{48} \mathrm{Zr}_{48} \mathrm{Al}_{2} \mathrm{Ag}_{2}, \mathrm{Cu}_{44} \mathrm{Zr}_{44} \mathrm{Al}_{6} \mathrm{Ag}_{6}$ and $\mathrm{Cu}_{40} \mathrm{Zr}_{40} \mathrm{Al}_{10} \mathrm{Ag}_{10}$ $\mathrm{BMGs}$ as the following research targets. Figure 2 shows the outer surface of the $\mathrm{Cu}-\mathrm{Zr}-\mathrm{Al}-\mathrm{Ag}$ alloy rods after compressive fracture. The fracture of the $\mathrm{Cu}_{48} \mathrm{Zr}_{48} \mathrm{Al}_{2} \mathrm{Ag}_{2}$ alloy rod occurred in a shear mode. The angle between the fracture surface and compression axis is close to $45^{\circ}$. The sample broke into two parts after compression test. As shown in Fig. 2(a), a large number of shear bands, indicated with arrows, appear on the outer surface of the fracture sample. Similar to the $\mathrm{Cu}_{48} \mathrm{Zr}_{48} \mathrm{Al}_{2} \mathrm{Ag}_{2}$ alloy, the $\mathrm{Cu}_{44} \mathrm{Zr}_{44} \mathrm{Al}_{6} \mathrm{Ag}_{6}$ alloy rod also broke into two parts with an angle of $45^{\circ}$ between the fracture surface and the compression axis. However, only one shear band was observed on the outer surface. For the $\mathrm{Cu}_{40} \mathrm{Zr}_{40} \mathrm{Al}_{10} \mathrm{Ag}_{10}$ alloy, the angle between the fracture surface and the compression axis is about $90^{\circ}$. Except for the part shown in Fig. 2(c), the other had broken
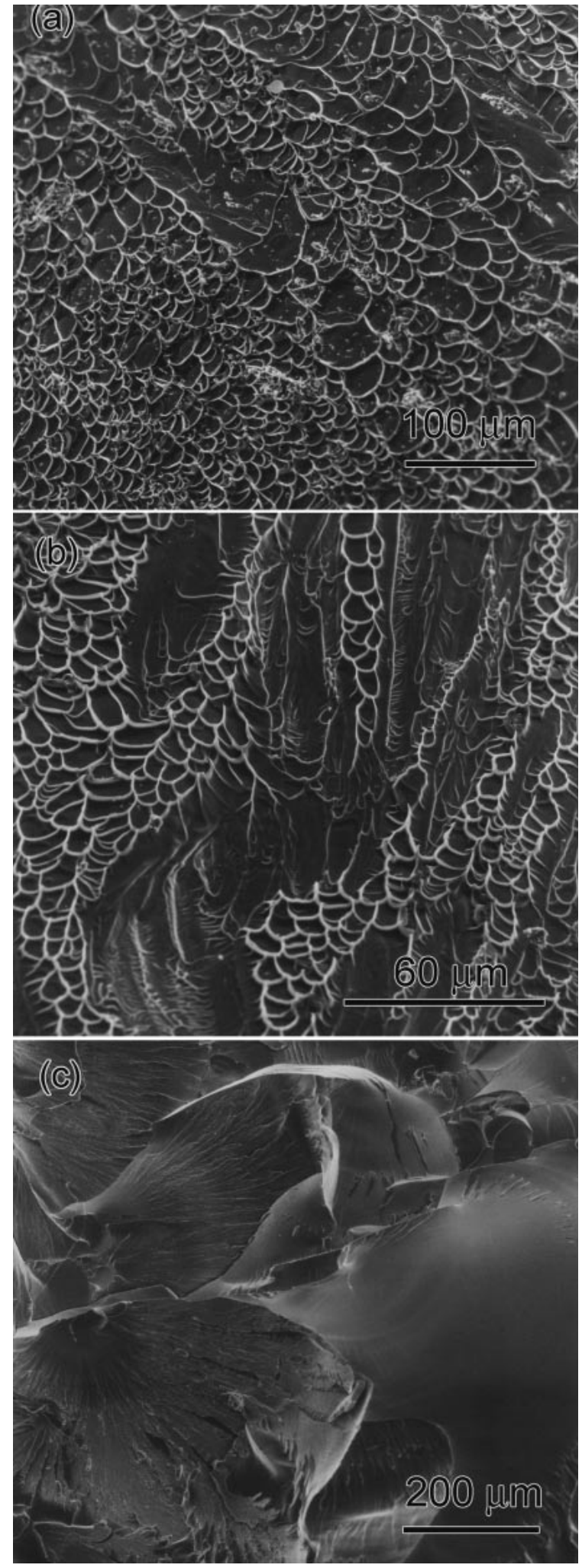

Fig. 3 SEM micrographs of the compressive fracture surface of the $\mathrm{Cu}-\mathrm{Zr}$ Al-Ag BMGs (a) $\mathrm{Cu}_{48} \mathrm{Zr}_{48} \mathrm{Al}_{2} \mathrm{Ag}_{2}$; (b) $\mathrm{Cu}_{44} \mathrm{Zr}_{44} \mathrm{Al}_{6} \mathrm{Ag}_{6}$; (c) $\mathrm{Cu}_{40} \mathrm{Zr}_{40^{-}}$ $\mathrm{Al}_{10} \mathrm{Ag}_{10}$.

into pieces. No evidence for a shear band was observed on the outer surface of the $\mathrm{Cu}_{40} \mathrm{Zr}_{40} \mathrm{Al}_{10} \mathrm{Ag}_{10}$ sample. Figure 3 shows the SEM images of the fracture surface of the $\mathrm{Cu}-\mathrm{Zr}$ $\mathrm{Al}-\mathrm{Ag}$ alloy rods. The fracture surface of the $\mathrm{Cu}_{48} \mathrm{Zr}_{48} \mathrm{Al}_{2} \mathrm{Ag}_{2}$ alloy rod exhibits a vein-like pattern. In addition, a lot of melted liquid balls appear on the surface for the $\mathrm{Cu}_{48^{-}}$ 


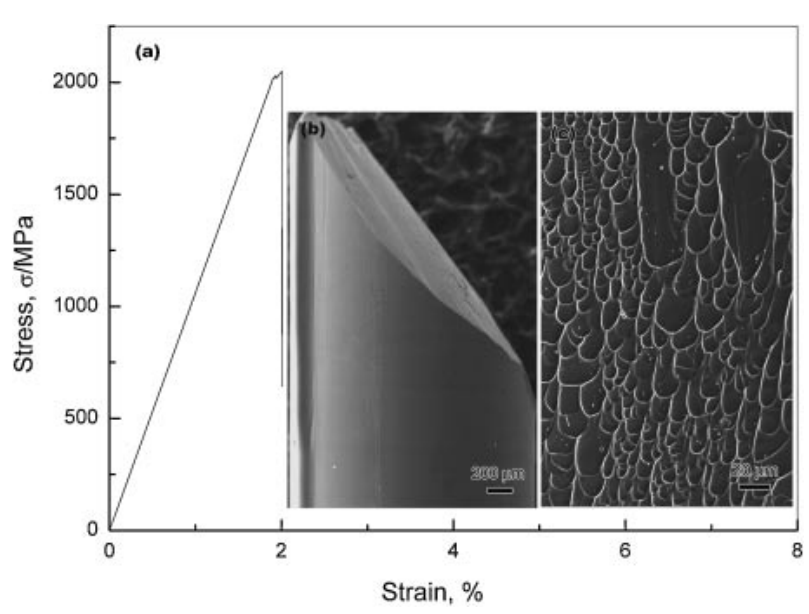

(A)

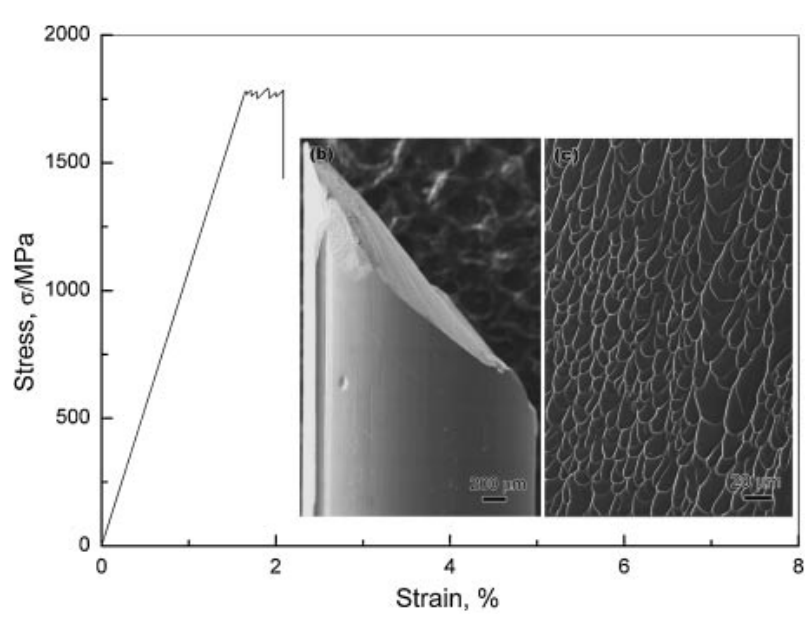

(B)

Fig. 4 Compressive stress-strain curves (a) and SEM images ((b), (c)) of the $\mathrm{Cu}_{45} \mathrm{Zr}_{45} \mathrm{Al}_{10}$ (A) and $\mathrm{Cu}_{45} \mathrm{Zr}_{45} \mathrm{Ag}_{10}$ (B) BMGs.

$\mathrm{Zr}_{48} \mathrm{Al}_{2} \mathrm{Ag}_{2}$ alloy rod, suggesting that a larger amount of strain along the shear band led to localized melting before fracture. For the $\mathrm{Cu}_{44} \mathrm{Zr}_{44} \mathrm{Al}_{6} \mathrm{Ag}_{6}$ alloy, the fracture surface exhibits a typical vein-like pattern of glassy alloys. In the case of $\mathrm{Cu}_{40} \mathrm{Zr}_{40} \mathrm{Al}_{10} \mathrm{Ag}_{10}$ alloy, the fracture surface exhibits a cleavage feature without any vein-like pattern, which is a characteristic of brittle fracture. These results clearly indicate that the glassy alloys make a transition from plasticity to brittleness as compositions change from $\mathrm{Cu}_{48} \mathrm{Zr}_{48} \mathrm{Al}_{2} \mathrm{Ag}_{2}$ to $\mathrm{Cu}_{40} \mathrm{Zr}_{40} \mathrm{Al}_{10} \mathrm{Ag}_{10}$. For comparison, we also examined the compressive properties of the ternary $\mathrm{Cu}_{45} \mathrm{Zr}_{45} \mathrm{Al}_{10}$ and $\mathrm{Cu}_{45}$ $\mathrm{Zr}_{45} \mathrm{Ag}_{10}$ BMGs. Figure 4 shows the compressive stressstrain curve and the fracture morphologies of the $\mathrm{Cu}_{45} \mathrm{Zr}_{45}$ $\mathrm{Al}_{10}$ and $\mathrm{Cu}_{45} \mathrm{Zr}_{45} \mathrm{Ag}_{10}$ glassy rods with a diameter of $2 \mathrm{~mm}$. The $\mathrm{Cu}_{45} \mathrm{Zr}_{45} \mathrm{Al}_{10}$ and $\mathrm{Cu}_{45} \mathrm{Zr}_{45} \mathrm{Ag}_{10}$ BMGs exhibit high yield strengths of about $1900 \mathrm{MPa}$ and plastic strains of about 0.2 0.3\%. As shown in Fig. 4, the $\mathrm{Cu}_{45} \mathrm{Zr}_{45} \mathrm{Al}_{10}$ and $\mathrm{Cu}_{45}-$ $\mathrm{Zr}_{45} \mathrm{Ag}_{10}$ BMGs failed in the same shear mode with a veinlike pattern on the fracture surface.

\section{Discussion}

The stress-strain curves and the appearance of fracture surfaces reveal a typical transition from plasticity to brittle-

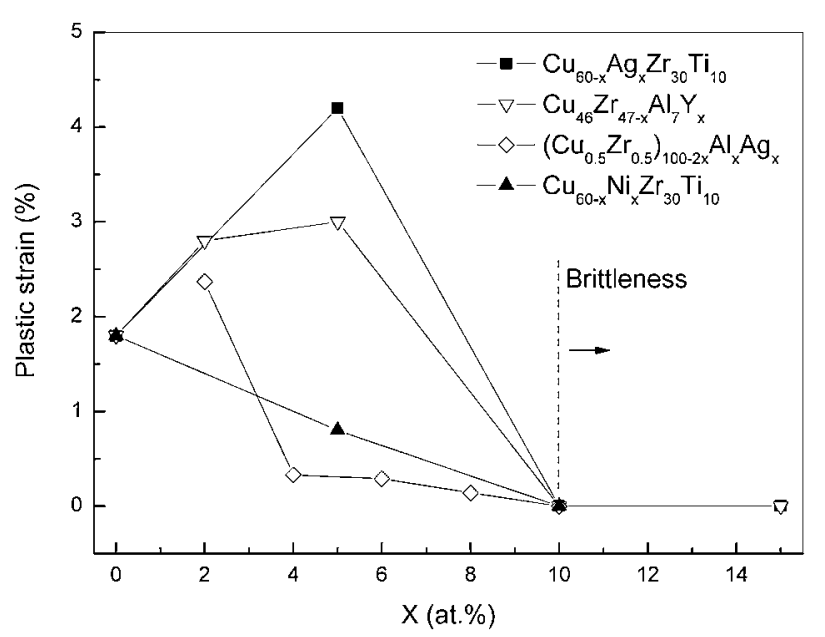

Fig. 5 Plastic strain as a function of the content $x$ of the alloying elements in $\mathrm{Cu}-\mathrm{Zr}$-based BMGs. The data of $\mathrm{Cu}-\mathrm{Zr}-\mathrm{Al}-\mathrm{Y}$ BMGs comes from ref. 14), the data of $\mathrm{Cu}-\mathrm{Ag}-\mathrm{Zr}-\mathrm{Ti}$ and $\mathrm{Cu}-\mathrm{Ni}-\mathrm{Zr}-\mathrm{Ti}$ comes from ref. 13).

ness in fracture mode for the $\mathrm{Cu}-\mathrm{Zr}-\mathrm{Al}-\mathrm{Ag} \mathrm{BMGs}$ with increasing the contents of $\mathrm{Al}$ and $\mathrm{Ag}$. It is noted that $\mathrm{Ag}$ has a high Poisson ratio of 0.37 as compared with $\mathrm{Zr}(0.34), \mathrm{Cu}$ (0.34) and $\mathrm{Al}(0.35)$. Actually, high content of $\mathrm{Ag}$ decreased the plastic strain of the $\mathrm{Cu}-\mathrm{Zr}$-based $\mathrm{BMGs}$, ${ }^{12)}$ inconsistent with Lewandowski's suggestion. ${ }^{2}$ It seems that the brittleness of the $\mathrm{Cu}_{40} \mathrm{Zr}_{40} \mathrm{Al}_{10} \mathrm{Ag}_{10} \mathrm{BMG}$ results from the addition of $\mathrm{Ag}$. However, the corresponding $\mathrm{Cu}_{45} \mathrm{Zr}_{45} \mathrm{Ag}_{10}$ glassy rod exhibited the same typical ductile fracture mode as the ternary $\mathrm{Cu}_{45} \mathrm{Zr}_{45} \mathrm{Al}_{10}$ BMG. It has been reported that enhanced plasticity can be obtained for the BMGs with an alloying element having a positive heat of mixing with some of the constituent elements, ${ }^{13,14)}$ such as $\mathrm{Cu}-\mathrm{Zr}-\mathrm{Ti}-\mathrm{Ag}, \mathrm{Cu}-\mathrm{Zr}$ $\mathrm{Ni}-\mathrm{Ti}$ and $\mathrm{Cu}-\mathrm{Zr}-\mathrm{Al}-\mathrm{Y}$ BMGs, in which $\mathrm{Cu}$ has a positive heat of mixing with $\mathrm{Ag}, \mathrm{Ni}$ and Y. Figure 5 summarizes the fluctuations of the plastic strain of the $\mathrm{Cu}-\mathrm{Zr}$-based BMGs as the content of the alloying elements increase. It is seen that the plasticity is only obtained in a limited composition range. Beyond the limited composition range, the $\mathrm{Cu}-\mathrm{Zr}$-based BMGs exhibit a brittle fracture mode. Park et al. ${ }^{13)}$ suggested that the addition of an alloying element having a positive heat of mixing might influence local chemical inhomogeneity, which affected the formation and propagation of the shear bands during deformation. However, they did not give an explanation for that higher content of alloying elements resulted in extreme brittleness for the $\mathrm{Cu}$-Zr-based BMGs. The plasticity or brittleness of the $\mathrm{Cu}-\mathrm{Zr}$-based BMGs is sensitive to not only the alloying elements but also the concentrations of the alloying elements.

Up to now, the detailed atomic structure of the glassy alloys has not been quantitatively established, especially for the multicomponent glassy alloys. Recently, Miracle ${ }^{15,16)}$ presented an efficient cluster packing model for metallic glasses, which combined random positioning of solvent atoms with atomic order of solutes. Good agreement between experiment and predication has been achieved for this model. For the $\mathrm{Cu}-\mathrm{Zr}$-based BMGs, let it be supposed that the $\mathrm{Cu}$ and $\mathrm{Zr}$ atoms are the solvent atoms and the other atoms such as $\mathrm{Al}, \mathrm{Ag}, \mathrm{Y}, \mathrm{Ni}$ and $\mathrm{Ti}$ are the solute atoms. It is noted that the heats of mixing for the $\mathrm{Cu} / \mathrm{Ag}$ or $\mathrm{Ni}$ and $\mathrm{Zr} / \mathrm{Y}$ atomic pairs 
are positive and the heat of mixing between $\mathrm{Al}$ and $\mathrm{Cu}$ is only $-1 \mathrm{~kJ} / \mathrm{mol}$, which means a low atomic binding force for the $\mathrm{Cu} / \mathrm{Ag}$ ( $\mathrm{Ni}$ or $\mathrm{Al}$ ), and $\mathrm{Zr} / \mathrm{Y}$ atomic pairs. ${ }^{10)}$ On the contrary, $\mathrm{Ag}, \mathrm{Al}$ and $\mathrm{Ni}$ have strong negative heats of mixing with $\mathrm{Zr}$, suggesting that strongly-bound atomic pairs may form among these atomic pairs. Consequently, the $\mathrm{Cu} / \mathrm{Ag}$ ( $\mathrm{Ni}$ or $\mathrm{Al}$ ), and $\mathrm{Zr} / \mathrm{Y}$ pairs might be the "weak" pairs in the efficient atomic dense packing of the $\mathrm{Cu}-\mathrm{Zr}-\mathrm{Al}-\mathrm{Ag}(\mathrm{Y})$ glassy alloys, which results in formation of the "weak point" in glassy structure. When the glassy alloys deforms under compressive loading, the "weak" atomic pairs might be easy to be broken as compared with the strongly-bound atomic pairs. As the content of the alloying elements increases, the number of the "weak" point will increase. When the number of "weak" points reaches a critical value, the glassy alloys might change to brittle. As shown in Fig. 3(c), the fracture surface of the brittle $\mathrm{Cu}_{40} \mathrm{Zr}_{40} \mathrm{Al}_{10} \mathrm{Ag}_{10} \mathrm{BMG}$ exhibits a cleavage pattern, not the typical vein-like pattern of the glassy alloys. This indicates that the failure of the $\mathrm{Cu}_{40} \mathrm{Zr}_{40} \mathrm{Al}_{10} \mathrm{Ag}_{10}$ BMG might result from the catastrophic split of the "weak" atomic pairs, not the viscous flow of the localized shear bands. Moreover, different from the shear mode of the ductile BMGs, the brittle $\mathrm{Cu}_{40} \mathrm{Zr}_{40} \mathrm{Al}_{10} \mathrm{Ag}_{10}$ glassy sample finally failed into a lot of pieces under compressive loading, which also shows that the catastrophic split of the "weak" atomic pairs leads to the failure of the glassy alloys. As consistent with our results, Zhang's work ${ }^{17)}$ also demonstrated that the fracture mode of the BMGs was related with the surface energy or bonding strength of the atomic pairs.

As cited in the above, the addition of $\mathrm{Y}, \mathrm{Ag}$ or $\mathrm{Ni}$ to $\mathrm{Cu}-\mathrm{Zr}$ based BMGs increases the "weak" atomic pairs and leads to brittleness. Nevertheless, the total brittleness of the BMGs requires enough content of these alloying elements. As shown in Figs. 1 and 5, the $\mathrm{Cu}-\mathrm{Zr}$-based BMGs with low contents of alloying elements exhibit a small amount of plastic deformation under compressive loading. This result indicates a small amount of "weak" atomic pairs cannot evidently degrade the intrinsic toughening of metallic glass. It exist a critical content of the alloying elements for the brittleness of BMGs. In addition, the $\mathrm{Cu}-\mathrm{Zr}$-based alloys with low contents of alloying elements usually always have a low glass-forming ability, and then the nanocrystalline phases easily precipitate from the glassy matrix. It has been reported that a positive heat of mixing also contributes to formation of nanocrystalline particles or chemical inhomogenity. ${ }^{14,18,19)}$ Therefore, the nanocrystalline particles in the ductile glassy matrix can stop the propagation of the shear bands and improve the plasticity of the BMGs with low content of alloying elements. ${ }^{18,19)}$ However, if the content of the alloying elements or the amount of the "weak" atomic pairs reaches the critical value, the metallic glasses will lose their intrinsic toughening. Under this condition, the metallic glasses will not exhibit any plasticity, even though the nanocrystalline phases precipitate from the glassy matrix.
Perhaps, a new correlation between the plasticity or brittleness and the content of alloying elements should be established to help us to design the ductile BMGs.

\section{Conclusions}

The present works show that the plasticity of the $\mathrm{Cu}-\mathrm{Zr}$ based BMGs decreases as the content of the alloying elements of $\mathrm{Al}$ and $\mathrm{Ag}$ increases. The plasticity of the $\mathrm{Cu}-$ Zr-based BMGs is only obtained by adding a limited content of the alloying elements. Beyond the limited composition range, the $\mathrm{Cu}-\mathrm{Zr}$-based $\mathrm{BMGs}$ exhibit a brittle fracture mode. A clear transition from plasticity to brittleness occurs for the $\mathrm{Cu}-\mathrm{Zr}$-based BMGs with increasing the content of $\mathrm{Al}$ and $\mathrm{Ag}$. The plasticity or brittleness of the $\mathrm{Cu}-\mathrm{Zr}$-based BMGs is sensitive to the concentrations of the alloying elements.

\section{Acknowledgements}

This work was financially supported by Research and Development Project on Advanced Metallic Glasses, Inorganic Materials and Joining Technology from the Ministry of Education, Science, Sports, and Culture of Japan.

\section{REFERENCES}

1) A. Inoue: Acta Mater. 48 (2000) 279-306.

2) J. J. Lewandowski, W. H. Wang and A. L. Greer: Philos. Mag. Lett. 85 (2005) 77-87.

3) J. J. Lewandowski, M. Shazly and A. Shamimi Nouri: Scr. Mater. 54 (2006) 337-341.

4) P. Lowhaphandu and J. J. Lewandowski: Scr. Mater. 38 (1998) 18111817.

5) P. Wesseling, T. G. Nieh, W. H. Wang and J. J. Lewandowski: Scr. Mater. 51 (2004) 151-154.

6) R. D. Conner, A. J. Rosakis, W. L. Johnson and D. M. Omen: Scr. Mater. 37 (1997) 1373-1378.

7) H. Kimura and T. Masumoto: Acta Metall. 28 (1980) 1663-1675.

8) X. K. Xi, D. Q. Zhao, M. X. Pan, W. H. Wang, Y. Wu and J. J. Lewandowski: Phys. Rev. Lett. 94 (2005) 125510.

9) Z. Bian, G. L. Chen, G. He and X. D. Hui: Mater. Sci. Eng. A316 (2001) 135-144

10) X. J. Gu, A. G. McDermott, S. J. Poon and G. J. Shiflet: Appl. Phys. Lett. 88 (2006) 211905.

11) Q. S. Zhang, W. Zhang and A. Inoue: the 5th International Conference on BMGs, Oct. 2006, Awaji, Japan.

12) W. Zhang and A. Inoue: J. Mater. Res. 21 (2006) 234-241.

13) E. S. Park, H. J. Chang, D. H. Kim, T. Ohkubo and K. Hono: Scr. Mater. 54 (2006) 1569-1573.

14) E. S. Park and D. H. Kim: Acta Mater. 54 (2006) 2597-2604.

15) D. B. Miracle: Nature Mater. 3 (2004) 697-702.

16) D. B. Miracle: Acta Mater. 54 (2006) 4317-4336.

17) Z. F. Zhang, H. Zhang, B. L. Shen, A. Inoue and J. Eckert: Phil. Mag. Lett. 86 (2006) 643-650.

18) Q. S. Zhang, H. F. Zhang, Z. W. Zhu and Z. Q. Hu: Mater. Trans. 46 (2005) 730-733.

19) J. Das, M. B. Tang, K. B. Kim, R. Theissmann, F. Baier, W. H. Wang and E. Eckert: Phys. Rev. Lett. 94 (2005) 205501. 